\title{
Landskapsfunksionaliteit en plantdiversiteit in stedelike en landelike gefragmenteerde grasvelde in die Potchefstroom omgewing
}

\begin{abstract}
Authors:
J.A.D. Breedt ${ }^{1}$

Ivan Brewer ${ }^{1}$

A. Coetzer ${ }^{1}$

L. van der Walt ${ }^{1}$

Sarel S. Cilliers ${ }^{1}$

Affiliations:

${ }^{1}$ School of Environmental

Sciences and Development,

Botany, North-West

University, South Africa

Correspondence to:

Tinus Breedt

Email:

tinus@arwyp.com

Postal address:

Private Bag X6001,

Potchefstroom Campus,

North-West University,

Potchefstroom 2520,

South Africa

How to cite this abstract:

Breedt, J.A.D., Brewer, I.,

Coetzer, A., Van der Walt,

L. \& Cilliers, S.S., 2012,

'Landskapsfunksionaliteit

en plantdiversiteit in

stedelike en landelike

gefragmenteerde grasvelde

in die Potchefstroom

omgewing', Suid-Afrikaanse

Tydskrif vir Natuurwetenskap

en Tegnologie 31(1), Art.

\#279, 1 page. http://dx.doi.

org/10.4102/satnt.v31i1.279

Note:

This abstract was initially presented at the annual

Biological Sciences

Symposium, presented

under the protection of the Suid-Afrikaanse Akademie vir Wetenskap en Kuns. The symposium was held at the University of Johannesburg on 01 October 2011.
\end{abstract}

(C) 2012. The Authors. Licensee: AOSIS OpenJournals. This work is licensed under the Creative Commons Attribution License.
Verstedeliking en die gepaardgaande antropogeniese impakte op ekosisteme neem voortdurend toe en tree as ' $n$ sterk selektiewe krag op wat plant-spesiediversiteit, ruimtelike verspreiding, funksionaliteit en gedrag van plantspesies beïnvloed. Relatief min studies word egter in hierdie verband in Suid-Afrika gedoen omdat die bewaringstatus van stedelike oop ruimtes soos byvoorbeeld gefragmenteerde grasvelde, laag is. Die perspesie bestaan dat grasvelde in stedelike gebiede in so ' $n$ mate versteur is dat dit nie meer so funksioneel en spesieryk soos natuurlike grasvelde is nie. Die bewaringstatus van grasvelde in Suid-Afrika is ook oor die algemeen laag en $30 \%$ van Suid-Afrika se Grasveldbioom is getransformeer en die oorblywende $70 \%$ is tot ' $n$ groot mate gefragmenteer. Verstedeliking en landbou-aktiwiteite is die dryfkrag agter fragmentering en transformering van die Randse Hoëveld Grasveld plantegroeitipe. Slegs 1\% van dié bedreigde plantegroeitipe word tans bewaar.

Die doel van die studie was om die funksionaliteit van gefragmenteerde grasvelde in landelike en stedelike gebiede in die Randse Hoëveld Grasveld plantegroeitipe te vergelyk, en dit in verband te bring met plantspesiesamestelling en- rykheid. Drie veranderlikes is ook verder gebruik om landskapsfunksionaliteit te bepaal, naamlik grondoppervlak stabiliteit, potensiaal van sirkulering van voedingstowwe, en infiltreringskapasiteit.

'n Totaal van 10 grasveldfragmente is geselekteer vir die studie in die Potchefstroom-omgewing, 5 in stedelike, en 5 in landelike omgewings. Die V-I-S ('Vegetation-Impervious-Soil') metode van kwantifisering van verstedeliking is gebruik om tussen stedelike en landelike gebiede te onderskei. Drie metodes is gebruik om die data te versamel, naamlik, (1) Landskapfunksionaliteits-analise ('Landscape Function Analysis' - LFA), (2) frekwensie-opnames en (3) gemiddelde punt-tot-plant afstand.

Die 11 grondoppervlak assesseringseienskappe van die landelike en stedelike grasveldfragmente is gereflekteer in die drie LFA veranderlikes, naamlik stabiliteit, infiltrering en voedingstofsirkulering. Daar was geen ooglopende verskille in stabiliteit tussen die landelike en stedelike fragmente nie. Die landelike gebied het wel hoër waardes vir infiltrering en voedingstofsirkulering gehad, alhoewel die verskille nie statisties betekenisvol was nie. Die voorkoms van kriptogame, organiese materiaal, en variasie in grondtekstuur mag aanleiding gee tot die subtiele verskille tussen funksionaliteits-indekse van stedelike en landelike fragmente. Verskille mag ook toegeskryf word aan die ruimtelike oriëntering van die grasvelde. Die landelike fragmente het ' $n$ hoër gemiddelde verhouding begroeide gebied $(81.34 \%$ kolle vs. $18.66 \%$ oop kolle), teenoor die stedelike landskappe (71.3\% kolle vs. $28.7 \%$ oop kolle) gehad.

Die spesiesamestelling van die grasveldfragemente het aansienlik gevarieer, maar uit DCA ordenings was dit duidelik dat sommige van die landelike grasvelde meer ooreenstemming met van die stedelike grasvelde getoon het as met van die ander landelike grasvelde. Landelike grasvelde (37 spesies) het 'n effens hoër gemiddelde spesierykheid getoon as stedelike grasvelde (34 spesies). Die Shannon-Weaver diversiteitsindeks van stedelike grasvelde was egter hoër as die van landelike grasvelde, terwyl die gelykheid ('evenness ${ }_{\text {var }}$ ') van stedelike grasvelde laer as dié van landelike grasvelde was. Stedelike gebiede het egter ' $n$ effens hoër persentasie uitheemse spesies $(19 \%)$ as landelike gebiede $(16 \%)$ getoon, wat aan spesifieke antropogeniese versteurings soos grassny, grondkompaksie en besoedeling, toegeskryf kan word. Die uitheemse spesies in beide landelike en stedelike gebiede was hoofsaaklik kruide.

Uit die resultate blyk dat grasveldfragmente in stedelike en landelike gebiede nie noemenswaardig ten opsigte van funksionaliteit en spesierykheid van mekaar verskil nie. Hieruit kan afgelei word dat die effek van verstedeliking nie die grasvelde in die Randse Hoëveld Grasveld in so 'n mate transformeer dat dit nie meer bewaringswaardig is nie. Om hierdie bevindings te bevestig moet 'n groter aantal grasveldfragmente in die toekoms bestudeer word en omgewingsfaktore veral ten opsigte van fisiese en chemiese grondaspekte in berekening gebring word. 